\title{
Housing Conditions Contribute to Underweight in Children: An Example From Rural Villages in Southeast Sulawesi, Indonesia
}

\author{
Tasnim Tasnim', Gouranga Dasvarma², Lillian Mwanri ${ }^{3}$ \\ ${ }^{1}$ School of Public Health, College of Mandala Waluya Kendari Health Science, Kendari, Indonesia; ${ }^{2}$ College of Humanities, Arts and Social Sciences, \\ Flinders University, Adelaide, SA; ${ }^{3}$ College of Medicine and Public Health, Flinders University, Adelaide, SA, Australia
}

Objectives: The prevalence of underweight in children under 5 years of age is anomalously high in Konawe District, Southeast Sulawesi Province, Indonesia. This state of affairs may be related to poor housing conditions, such as limited access to clean water, the absence of a sanitary latrine, and the use of poor housing materials. Therefore, this study aimed to examine the effect of housing conditions on underweight in under-5 children in Konawe District.

Methods: This study was conducted in 2013 in 5 health centres in Konawe District, Southeast Sulawesi Province, and used a case-control study design. The study recruited 400 under-5 children, including 100 of whom were cases and 300 of whom were age-matched controls (1:3). Cases were underweight children, while the controls were children with a normal nutritional status. The independent variables were the availability and types of water and latrine facilities and housing materials (roof, wall, and floor). The statistical analysis used Cox regression.

Results: A lack of water availability (odds ratio [OR], 5.0; $95 \%$ confidence interval [Cl], 2.7 to $9.5 ; p<0.001$ ), a lack of latrine availability in the home $(\mathrm{OR}, 2.5 ; 95 \% \mathrm{Cl}, 1.5$ to $4.0 ; p<0.001)$, and poor-quality roofing materials $(\mathrm{OR}, 1.7 ; 95 \% \mathrm{Cl}, 1.1$ to $2.7 ; p<0.02)$ significantly contributed to underweight in children. In contrast, the walls and the floors did not contribute to under- 5 year children being underweight ( $p=0.09$ and $p=0.71$, respectively).

Conclusions: Sanitation facilities and roofing were identified as important factors to address in order to improve children's nutritional status. Children's health status was directly impacted by food intake via their nutritional status.

Key words: Living facilities, Child, Case-control studies, Underweight, Nutritional status, Indonesia

Received: March 24, 2017 Accepted: September 7, 2017

Corresponding author: Tasnim Tasnim, PhD

G-37, Kendari 93232, Southeast Sulawesi Province, Indonesia

Tel/Fax: +62-401-39-3176

E-mail: tasnim_ialf@yahoo.com

This is an Open Access article distributed under the terms of the Creative Commons Attribution Non-Commercial License (http://creativecommons.org/licenses/by$\mathrm{nc} / 4.0 /$ ) which permits unrestricted non-commercial use, distribution, and reproduction in any medium, provided the original work is properly cited.

\section{INTRODUCTION}

Underweight in children under 5 years of age remains a crucial issue in rural villages in Southeast Sulawesi Province, Indonesia, including Konawe District. In 2010, the prevalence of underweight in children under 5 years of age in Southeast Sulawesi was higher (16.3\%) than the national average (13.0\%) [1]. The target of the Millennium Development Goals in 2015 
was 15.5\%; thus, the Southeast Sulawesi government had to reduce the prevalence of underweight in children by 0.8 percentage points in 2015. This was challenging because the highest prevalence of underweight children was in rural villages, and underweight is known to be caused by a diverse range of social, economic, cultural, and political factors. Underweight under- 5 children experience substantially increased mortality and overall disease burden [2]. It is also common knowledge that underweight in under-5 children is associated with decreased productivity, resulting in a vicious cycle of poverty in affected families, communities, and nations [3]. Some rural communities include low-income families. Approximately $42.3 \%$ of people who lived in rural villages in Konawe District had incomes below the poverty line in 2010 [4]. These individuals lived in poor housing conditions, with insufficient clean water sources, and some of them did not have a sanitary latrine in their home. As reported by the Health Department of Southeast Sulawesi [5], only 5.3\% of households had access to clean water facilities such as piped water facilities in their home, although $56.8 \%$ of rural families had a sanitary latrine, such as a pour-flush latrine, in their home. These conditions may contribute to the high incidence of diarrhoea in Konawe District, which was $56.2 \%$ in under-5 children in 2011. Cough and pneumonia were also found to be common in these rural villages. Infectious diseases, including diarrhoea, cough, and pneumonia, reduce children's appetite, thereby contributing to inadequate nutritious food intake in addition to their deleterious effects on metabolism.

Several studies have been conducted to elucidate the causes of underweight in children in Indonesia. However, these studies have mainly focused on parental education and income. Limited research has been conducted into the contributions of housing conditions, such as the materials of the roof, the walls, and the floor of the house, and the type of water and latrine facilities available in the home. Therefore, it is necessary to investigate whether housing materials and the type and availability of water and latrine facilities in the home contribute to underweight in under-5 children in rural villages. Doing so in Konawe District was the aim of this study. In particular, the objective of this study was to investigate the relationship of the availability and type of water and latrine facilities in the home and housing materials (roof, walls, and floor) with underweight in under-5 children in rural villages in Konawe District.

\section{METHODS}

\section{Study Design}

This quantitative study applied a case-control design, because this design enables the assessment of multiple causes relating to a condition such as underweight in children [6]. The case-control study was conducted from December 16, 2012 to February 2, 2013 in 5 community health centres in Konawe District, Southeast Sulawesi Province. A case was defined as an underweight child aged 0-59 months, as indicated by a Zscore of weight-for-age (WA) lower than -2 standard deviations (SDs) [7]. The case group was composed of such children. In contrast, controls were children aged 0-59 months with a WA of -2 SD $<$ Z-score $<+2$ SD; in other words, the control group was composed of children with a normal nutritional status. Children's nutritional status was the dependent variable in this study. The independent variables were the availability and the type of water and latrine facilities and housing materials (roof, wall, and floor). The objective criteria for the independent variables were as follows:

a) The availability of water facilities was defined based on the presence of a clear-water facility in the home that was used by the family for their daily activities. This parameter was categorized as (1) "yes," if the family had clean water facilities in the home; or (2) "no," if they did not. Piped water or a deep well was defined as a safe water facility located inside the house, while a superficial well, a communal water supply was defined as a poor water facility; b) The availability of a latrine was defined based on the presence of a sanitary latrine facility on the family's property. There were two answers to this question: (1) "yes," if a latrine facility was present on the family's property, either inside or outside; or (2) "no," if no latrine facility was present on the family's property. Pour-flush latrines were categorized as a sanitary latrine facility in the home, while other types such as ventilated and simple pits were categorized as medium-quality latrine facilities. Use of the sea, a river, or a garden was defined as a poor latrine facility; (C) The roof was evaluated according to the materials used for its construction. Iron sheets and tiles were classified as high-quality roofing materials, while thatch, grass, and other materials were classified as poor-quality materials; (D) The walls were evaluated according to the materials used in their construction. Bricks, cement, and cement blocks were classified as high-quality materials, while bamboo sheets and wood were classified as poor-quality materials; and e) The floor was evaluated accord- 
ing to the materials used for the construction of the floor. Ceramic was classified as a high-quality material for the floor, cement as a medium-quality material, and earth, wood, and plastic were classified as poor-quality materials.

\section{Population and Sample of This Study}

The population of this study was all children under 5 years of age in 5 villages in Konawe District, while the sample of this study was 400 under- 5 children. They were recruited from the register of the childhood nutritional program in the 5 community health care centres. The sample size was calculated using the Kelsey et al. [8] model of sample size calculation for casecontrol studies at a case-to-control ratio of 1:3. A 2-sided significance level (alpha) of 0.05 was used, as well as $80 \%$ power and $95 \%$ confidence intervals $(\mathrm{Cl})$. A case-to-control ratio of 1:3 was used to improve the rigor and power of this study [9]. Cases less than 11 months old were matched with a control of the same age, while cases aged 12-59 months were matched with controls of a similar age. In each of the 5 community health care centres, 20 cases were identified, and these were then matched with 60 controls from the same community health care centre. The children's mothers or guardians were also invited to participate in structured interviews in the form of a questionnaire.

\section{Data Analyses}

Data were analysed using both univariate and multivariate analyses. The univariate analysis examined the demographic characteristics of respondents (children and mothers) and housing conditions (i.e., water facilities, latrines, and the house's construction materials). Cross-tabulations were employed to compare these variables between the case and the control groups. The multivariate analysis was conducted using logistic regression in SPSS version 20.0 (IBM Corp., Armonk, NY, USA). The $p$-values less than 0.05 on the chi-square test were considered to indicate significant associations. The reference category for all models was the category assumed to have the least risk. For water facilities in the home, this was the availability of piped water or a deep well. The reference category of latrine facilities in the home was availability of a pour-flush latrine in the home. Iron sheet/tiles were used as the reference category for the roof materials. Bricks and cement/cement blocks were the reference category for the wall materials. Finally, ceramic was the reference category for the floor materials.
Table 1. Descriptive information of children's characteristics

\begin{tabular}{lcc}
\hline & Cases $(\mathbf{n}=\mathbf{1 0 0})$ & Controls $(\mathbf{n}=\mathbf{3 0 0})$ \\
\hline Sex & & \\
Male & $55(55.0)$ & $162(54.0)$ \\
Female & $45(45.0)$ & $138(46.0)$ \\
Age (mean \pm SD) & $29.5 \pm 13.2$ & $26.8 \pm 14.4$ \\
Sickness & & \\
Yes & $79(79.0)$ & $130(43.3)$ \\
No & $21(21.0)$ & $56.7(47.8)$ \\
Diseases & & \\
Diarrhoea & $4(4.0)$ & $8(2.7)$ \\
Malaria & $1(1.0)$ & $0(0.0)$ \\
Measles & $0(0.0)$ & $2(0.7)$ \\
Cough & $32(32.0)$ & $48(16.0)$ \\
Pneumonia & $1(1.0)$ & $2(0.7)$ \\
Fever/influenza & $68(68.0)$ & $107(35.7)$ \\
\hline
\end{tabular}

Values are presented as number (\%).

SD, standard deviation.

${ }^{1}$ Sickness during the past 2 weeks.

\section{RESULTS}

\section{Characteristics of the Children in the Case and Control Groups}

In the total sample, there were 217 male children and 183 female children. The distribution of male and female children under the age of 5 years was almost equal in the cases and the controls (Table 1). A much higher proportion of the cases (79.0\%) compared to controls (43.3\%) reported an illness during the 2 weeks prior to the study. The most frequently reported symptoms were fever or influenza for both the cases and the controls ( $68.0 \%$ in cases vs. $35.7 \%$ in controls), followed by cough, which was reported by $32.0 \%$ of the cases and $16.0 \%$ of the controls.

\section{Housing Facilities and Materials}

This study found that a high proportion of underweight children lived in houses without clean water facilities (31.0\%) (such as no piped water facilities), no latrine facilities (41.0\%) (including no pour-flush latrine), a roof made of thatch or grass $(46.0 \%)$, a wall made of bamboo sheets $(70.0 \%)$, and floors made of earth or wood (14.0\%) (Table 2).

\section{Relationship Between Housing Conditions and Underweight in Under-5 Children}

Several independent variables made a significant contribution to underweight in under- 5 children, including a lack of 
Table 2. The contributions of the availability of water and latrine facilities and housing materials (roof, wall, and floor) to underweight in under-5 children by univariate analysis

\begin{tabular}{|c|c|c|c|c|}
\hline & Cases $(n=100)$ & Control $(n=300)$ & OR $(95 \% \mathrm{CI})^{1}$ & $p$-value \\
\hline \multicolumn{5}{|l|}{ Availability of water facility at home } \\
\hline Yes & $69(69.0)$ & $273(91.0)$ & 1.0 (reference) & \\
\hline No & $31(31.0)$ & $27(9.0)$ & $5.0(2.7,9.5)$ & $<0.001$ \\
\hline \multicolumn{5}{|l|}{ Type of water facility at home } \\
\hline Piped water/deep well & $36(36.0)$ & $170(56.7)$ & 1.0 (reference) & \\
\hline Superficial well & $33(33.0)$ & $103(34.3)$ & $2.2(1.1,4.2)$ & $<0.01$ \\
\hline Communal/shared & $31(31.0)$ & $27(9.0)$ & $7.8(3.7,16.6)$ & $<0.001$ \\
\hline \multicolumn{5}{|l|}{ Availability of latrine at home } \\
\hline Yes & $59(59.0)$ & $233(77.7)$ & 1.0 (reference) & \\
\hline No & $41(41.0)$ & $67(22.3)$ & $2.5(1.5,4.0)$ & $<0.001$ \\
\hline \multicolumn{5}{|l|}{ Type of latrine at home } \\
\hline Pour-flush & $49(49.0)$ & $190(63.0)$ & 1.0 (reference) & \\
\hline Simple/ventilated pit & $14(14.0)$ & $52(17.3)$ & $1.1(0.5,2.1)$ & 0.88 \\
\hline Sea/river/garden/others & $37(37.0)$ & 58 (19.3) & $2.6(1.5,4.4)$ & $<0.001$ \\
\hline \multicolumn{5}{|l|}{ Roof of the house } \\
\hline Iron sheet/tiles & $54(54.0)$ & $201(67.0)$ & 1.0 (reference) & \\
\hline Thatch/grass/others & $46(46.0)$ & $99(33.0)$ & $1.9(1.1,3.1)$ & $<0.01$ \\
\hline \multicolumn{5}{|l|}{ Wall of the house } \\
\hline Bricks and cement/cement block & $30(30.0)$ & $116(38.7)$ & 1.0 (reference) & \\
\hline Bamboo sheets/wood & $70(70.0)$ & $184(61.3)$ & $1.6(0.9,2.7)$ & 0.09 \\
\hline \multicolumn{5}{|l|}{ Floor of the house } \\
\hline Ceramic & $14(14.0)$ & $48(16.0)$ & 1.0 (reference) & \\
\hline Cement & $72(72.0)$ & $218(72.7)$ & $1.2(0.6,2.3)$ & 0.68 \\
\hline Earth/wood/plastic & $14(14.0)$ & $34(11.3)$ & $1.5(0.6,3.6)$ & 0.42 \\
\hline
\end{tabular}

Values are presented as number (\%).

$\mathrm{OR}$, odds ratio; $\mathrm{Cl}$, confidence interval.

'Using logistic regression.

water and latrine availability in the home and the roof of the house $(p<0.001$ ) (Tables 2 and 3). For example, children from households with no water facilities in the home were 5 times more likely to be underweight than children from households where water facilities were available in the home (odds ratio [OR], $5.0 ; 95 \% \mathrm{Cl}, 2.7$ to $9.5 ; p<0.001)$. Children who lived in thatched or grass-roof houses were 1.9 times more likely to be underweight than children who lived in houses constructed with corrugated iron sheets or with tiled roofs $(\mathrm{OR}, 1.9 ; 95 \% \mathrm{Cl}$, 1.1 to $3.1 ; p<0.01$ ).

\section{DISCUSSION}

A lack of clean water facilities (piped water or deep well) in the family home was found to be a strong predictor of underweight in children under 5 years of age. Approximately $64 \%$ of underweight children lived in homes with a superficial well or communal/shared water facilities. The physical condition of the water in some of the superficial wells was very poor. The water was yellow and turbid. This condition was caused by the mining industry in Konawe District. Low-income families used communal or shared water facilities that were built by the local government in 1995. Thus, the construction and sanitation of communal water facilities was very poor. It is therefore logical that the absence of clean water in the home may have increased the transmission of infectious diseases in children under 5 years old, via inadequate sanitation practices for daily activities, such as food preparation and child feeding practices. Diarrhoea and other parasitic infections are often caused by a lack of clean water in the home [10], as insects (vectors of infectious diseases) prefer to live and breed in the water, including home water storage systems [11]. As suggested by PrüssUstün et al. [12], schistosomasis and lymphatic filariasis are more common in households without clean water in the 
Table 3. The contributions of the availability of water and latrine facilities and housing materials (roof, wall, and floor) to underweight in under-5 children by multivariate analysis

\begin{tabular}{|c|c|c|c|c|}
\hline & Cases $(n=100)$ & Control $(n=300)$ & OR $(95 \% \mathrm{CI})^{1}$ & $p$-value \\
\hline \multicolumn{5}{|l|}{ Availability of water facility at home } \\
\hline Yes & $69(69.0)$ & $273(91.0)$ & 1.0 (reference) & \\
\hline No & $41(41.0)$ & $67(22.3)$ & $4.5(2.5,8.1)$ & $<0.001$ \\
\hline \multicolumn{5}{|l|}{ Type of water facility at home } \\
\hline Piped water/deep well & $36(36.0)$ & $170(56.7)$ & 1.0 (reference) & \\
\hline Superficial well & $33(33.0)$ & $103(34.3)$ & $2.1(0.9,4.7)$ & 0.07 \\
\hline Communal/shared & $31(31.0)$ & $27(9.0)$ & $7.5(3.2,18.0)$ & $<0.001$ \\
\hline \multicolumn{5}{|l|}{ Availability of latrine at home } \\
\hline Yes & $59(59.0)$ & $233(77.7)$ & 1.0 (reference) & \\
\hline No & $41(41.0)$ & $67(22.3)$ & $2.4(1.5,3.9)$ & $<0.001$ \\
\hline \multicolumn{5}{|l|}{ Type of latrine at home } \\
\hline Pour-flush & $49(49.0)$ & $190(63.0)$ & 1.0 (reference) & \\
\hline Simple/ventilated pit & $14(14.0)$ & $52(17.3)$ & $1.0(0.5,2.0)$ & 0.90 \\
\hline Sea/river/garden/others & $37(37.0)$ & $58(19.3)$ & $2.5(1.5,4.2)$ & $<0.001$ \\
\hline \multicolumn{5}{|l|}{ Roof of the house } \\
\hline Iron sheet/tiles & $54(54.0)$ & $201(67.0)$ & 1.0 (reference) & \\
\hline Thatch/grass/others & $46(46.0)$ & $99(33.0)$ & $1.7(1.1,2.7)$ & $<0.02$ \\
\hline \multicolumn{5}{|l|}{ Wall of the house } \\
\hline Bricks and cement/cement block & $30(30.0)$ & $116(38.7)$ & 1.0 (reference) & \\
\hline Bamboo sheets/wood & $70(70.0)$ & $184(61.3)$ & $0.1(0.0,0.9)$ & 0.04 \\
\hline \multicolumn{5}{|l|}{ Floor of the house } \\
\hline Ceramic & $14(14.0)$ & $48(16.0)$ & 1.0 (reference) & \\
\hline Cement & $72(72.0)$ & $218(72.7)$ & $\mathrm{N} / \mathrm{A}$ & - \\
\hline Earth/wood/plastic & $14(14.0)$ & $34(11.3)$ & $1.5(0.8,3.1)$ & 0.21 \\
\hline
\end{tabular}

Values are presented as number (\%).

$\mathrm{OR}$, odds ratio; $\mathrm{Cl}$, confidence interval; N/A, not applicable.

${ }^{1}$ Uing logistic regression.

home or adequate sanitation. These illnesses cause undernutrition in under- 5 children because they are susceptible to these diseases and they have low immunity [13]. This study found an almost doubled prevalence of reported diarrhoea among children under 5 years of age who lived in an environment without an adequate supply of clean water. In addition to diarrhoea, malaria, dengue fever, and Japanese encephalitis are also impacts of limited water resources [12]. Diarrhoea and other infectious diseases reduce children's food intake and nutrient absorption [14]. Three children also experience a loss of appetite, thus leading to lower food intake [14]. Access to water and sanitation facilities is the most important factor in this regard, followed by the quality of water and sanitation, as well as individuals' behaviour relating to these facilities [12].

However, $36 \%$ of underweight children were found in highincome families who had access to clean water facilities such as piped water or deep wells. This means that the determi- nants of underweight in under- 5 children were not limited to the availability of water in the home, but also included other factors, such as children's health status and parental behaviour related to child-feeding practices [15]. Children's health status is affected by many factors, including environmental health and their immunity. Thus, if a child gets an infectious disease, such as diarrhoea, they will become hosts who transmit the disease to others, especially those with low immunity.

A lack of latrine facilities in the family home also increased the risk of children under 5 years old being underweight. The absence of latrine facilities in the home causes faecal contamination of the water storage, thus leading to an increase in parasitic infections, such as diarrhoea. Additionally, faecal contamination of children's food and drinking water can also take place through fingers, flies, soil, and waterborne sewage [16]. Therefore, if if neighbourhoods have not been managed hygienically, and practices such as not having a latrine in the 
home are commonplace, the surrounding area will be contaminated [17]. Moreover, the distance between the water resource and the latrine is a concern. Placing them close to each other risks contamination of the water resource, resulting in an increased burden of diarrhoeal and other diseases [17].

In this study, roofing materials of thatch or grass were also predictors of children under 5 years of age being underweight. A possible explanation for this is that roofs made of thatch or grass can be a breeding place for the propagation of insects that can act as vectors of diseases. Thatched roofing has been found to provide a space for protozoan parasites of the genus Leishmania [18]. People who are infected by this parasite suffer from visceral leishmaniasis, which can result in death, particularly in vulnerable groups such as under-5 children [18]. Another Indonesian study found a high number of rats in houses with roofing materials of thatch or grass. These roofing materials can easily be broken down by the rats, who are then able to take up residence in the house [19]. A high level of rat infestation can lead to the contamination of food and the transmission of diseases and viruses such as Lassa fever, cowpox, or Streptobacillus moniliformis [19]. People who are infected by any of these pathogens are susceptible to a disease known as human epizootic Haverhill fever, with symptoms such as fever and malaise [19]. The high proportion of fever cases reported in this study may have been caused by the consumption of food contaminated by parasites or viruses transmitted by rats. The use of poor housing materials is associated with low-incomes and low education levels [20]. This was also the case in this study, where thatch and grass materials for roofs were predominantly used by families with a lowincome and a low level of education. This means that these families might have no refrigerators or food covers, so that food is more easily contaminated by rats or flies. Furthermore, people with a low level of education also tend to have poor health knowledge, and are less aware of hygienic practices related to food for children [21].

In this study, the material used to construct the walls of the house was not found to have a significant relationship with underweight in children. This is in contrast to other studies that have found that the materials used in the construction of the walls in low-income dwellings increased the risk of respiratory diseases among children under 5 years of age [22]. For example, walls made of bamboo or wood tend to lead to increased dust levels inside the house, which might bring bacteria and are inhaled by vulnerable children, who then suffer from upper or lower respiratory infections. These walls also have poor ventilation, which causes high humidity levels inside the house; humidity, in turn, generates high growth levels of fungi, bacteria, amoebae, algae, or arthropod allergens, thus creating conditions that cause respiratory symptoms such as coughs [23]. The present study found no association between the materials used in the construction of the walls in a house with children's nutritional status, and likewise found no significant relationship with morbidity.

This study also found that flooring materials were not a predictor of children under the age of 5 years being underweight. This finding goes against the widely held view that dirt, earthen, or wooden floors are poor housing materials for children under 5 years of age [24]. This is because dirt floors increase the level of dampness inside the houses, which can then increase the growth of bacteria, such as Streptococcus species, and cause pneumonia [22]. Having an earth floor was found to increase the risk of pneumonia in children under 5 years of age by 3.9 times [22]. Moreover, earth or dirt floors can also become home to insects that transmit the parasitic protozoan Trypanosoma cruzi, which can cause Chagas disease [22]. Floor materials likely did not affect children's nutritional status because the majority of respondents' houses used cement as the flooring material (72.0\% of cases and $72.2 \%$ of controls). Another reason is that children under 5 years of age in Konawe District are not in direct contact with the floor, so the floor does not directly contribute to illnesses in the children. This is because an infant is usually carried by the mother, while older children often wear shoes or sandals when they play.

\section{Limitations and Implications for Public Health Policy and Practices}

It is important to note that this study was conducted in Konawe District, and more specifically, among families contacted through the 5 health care centres. Thus, our findings cannot be generalized to the whole population either of Southeast Sulawesi Province or of Indonesia. This study did not analyse the relationship between housing conditions and families' socioeconomic status. Thus, our explanations of the relationships between housing conditions and families' socioeconomic status were based on previous studies conducted in Indonesia and other countries.

As described above, this study found evidence that the availability of clean water, sanitary latrines, and the quality of the roof of a house play an important role in preventing chil- 
dren from becoming underweight. This evidence can be used by public health policy makers and health practitioners in this province to improve children's nutritional status. Using a filter in the water storage system is the most effective intervention to minimize the risk of water source contamination [25]. Such interventions can decrease the prevalence of diarrhoea by 30 to $40 \%$ [17]. The World Health Organization also made 6 suggestions to local governments [26]. First, local governments must ensure that communities in both urban and rural areas have access to clean water and sanitation. As found in this study, some communities in rural areas had no access to clean water facilities (i.e., piped water) or sanitary latrines (i.e., pourflush latrines). The quality of water and environmental protection measures must be also improved. Horizontal cooperation in planning and environmental policy must be done by the local governments to increase the sustainability of the management of water and sanitation facilities.

\section{ACKNOWLEDGEMENTS}

My sincere and special thanks go to the Konawe District Health Department and the mothers who participated in this study. I am grateful to the Prevention, Promotion and Primary Health Care Cluster, School of Medicine, Flinders University for financial support of this study.

\section{CONFLICT OF INTEREST}

The authors have no conflict of interest associated with the material presented in this paper.

\section{ORCID}

Tasnim Tasnim http://orcid.org/0000-0002-5322-082X

Gouranga Dasvarma http://orcid.org/0000-0002-1784-7967

Lillian Mwanri http://orcid.org/0000-0002-5792-7785

\section{REFERENCES}

1. National Institute of Health Research and Development, Ministry of Health. Indonesia basic health research 2010. Jakarta: Ministry of Health; 2010, p. 19 (Indonesian).

2. Bundara N, Mwanri L, Masika J. Addressing childhood under nutrition in Tanzania: challenges and opportunities. Afr J Food Agric Nutr Dev 2013;13(1):7288-7306.
3. de Onis M, Blössner M, Borghi E. Prevalence and trends of stunting among pre-school children, 1990-2020. Public Health Nutr 2012;15(1):142-148.

4. Statistic Indonesia. Poverty rate in Sulawesi Tenggara Province by regency/city, 2010-2014 [cited 2017 Sep 19]. Available from: https://sultra.bps.go.id/linkTableDinamis/view/id/62 (Indonesian).

5. Health Department of Southeast Sulawesi Province. Health profile of southeast Sulawesi Province in 2012 [cited 2017 Sep 19]. Available from: http://www.depkes.go.id/resources/ download/profil/PROFIL_KES_PROVINSI_2012/27_Profil_Kes. Prov.SulawesiTenggara_2012.pdf (Indonesian).

6. Elwood JM. Critical appraisal of epidemiological studies and clinical trials. Melbourne: Oxford University Press; 2007, p. 33.

7. Centers for Disease Control and Prevention; World Food Programme. A manual: measuring and interpreting malnutrition and mortality. Rome: World Food Programme; 2005, p. 20.

8. Kelsey JL, Thompson WD, Evans AS. Methods in observational epidemiology. New York: Oxford University Press; 1986, p. 122125.

9. Bryman A. Social research methods. New York: Oxford University Press; 2012, p. 197-198.

10. Yang C, Sangthong R, Chongsuvivatwong V, McNeil E, Lu L. Effect of village income and household income on sanitation facilities, hygiene behaviours and child undernutrition during rapid economic growth in a rural cross-border area, Yunnan, China. J Epidemiol Community Health 2009;63(5):403-407.

11. World Health Organizaion. Action against dengue: dengue day campaigns across Asia; 2011 [cited 2017 Sep 8]. Available from: http://www.wpro.who.int/emerging_diseases/documents/ActionAgainstDengue.pdf.pdf?ua $=1$.

12. Prüss-Ustün A, Bartram J, Clasen T, Colford JM Jr, Cumming O, Curtis V, et al. Burden of disease from inadequate water, sanitation and hygiene in low- and middle-income settings: a retrospective analysis of data from 145 countries. Trop Med Int Health 2014;19(8):894-905.

13. Pramod Singh GC, Nair M, Grubesic RB, Connell FA. Factors associated with underweight and stunting among children in rural Terai of eastern Nepal. Asia Pac J Public Health 2009;21 (2):144-152.

14. Silva RR, da Silva CA, de Jesus Pereira CA, de Carvalho Nicolato RL, Negrão-Corrêa D, Lamounier JA, et al. Association between nutritional status, environmental and socio-economic factors and Giardia lamblia infections among children aged 6-71 months in Brazil. Trans R Soc Trop Med Hyg 2009;103(5): 
512-519.

15. Zhang J, Shi J, Himes JH, Du Y, Yang S, Shi S, et al. Undernutrition status of children under 5 years in Chinese rural areas data from the National Rural Children Growth Standard Survey, 2006. Asia Pac J Clin Nutr 2011;20(4):584-592.

16. Gamboa MI, Navone GT, Orden AB, Torres MF, Castro LE, Oyhenart EE. Socio-environmental conditions, intestinal parasitic infections and nutritional status in children from a suburban neighborhood of La Plata, Argentina. Acta Trop 2011;118(3): 184-189.

17. Wolf J, Prüss-Ustün A, Cumming O, Bartram J, Bonjour S, Cairncross $S$, et al. Assessing the impact of drinking water and sanitation on diarrhoeal disease in low- and middle-income settings: systematic review and meta-regression. Trop Med Int Health 2014;19(8):928-942.

18. Kesari S, Bhunia GS, Kumar V, Jeyaram A, Ranjan A, Das P. Study of house-level risk factors associated in the transmission of Indian Kala-azar. Parasit Vectors 2010;3:94.

19. Fidiyani M. Elimination to bubonic plaque in Praja Mangkunegaran in 1915-1929. Avatara 2013;1(1):16-22 (Indonesian).

20. World Health Organization. Closing the gap in a generation: health equity through action on the social determinants of health; 2008 [cited 2017 Sep 8]. Available from: http://www. who.int/social_determinants/final_report/csdh_finalreport_2008_execsumm.pdf.

21. Bose $S$. The effect of women's status and community on the gender differential in children's nutrition in India. J Biosoc Sci
2011;43(5):513-533.

22. Yuwono TA. Factors of housing environment related to the incidence of pneumonia in under five year olds in community health centre of Kawunganten, Cilacap district; 2008 [cited 2017 Sep 19]. Available from: https://core.ac.uk/download/ pdf/11717742.pdf (Indonesian).

23. Braubach M, Jacobs DE, Ormandy D. Environmental burden of disease associated with inadequate housing: methods for quantifying health impacts of selected housing risks in the WHO European Region; 2011 [cited 2017 Sep 10]. Available from: http://www.euro.who.int/_data/assets/pdf_file/0003/ 142077/e95004.pdf.

24. World Health Organization (WHO). Developing guidance for health protection in the built environment-mitigation and adaptation responses. In: WHO. WHO workshop on housing, health and climate change. Geneva; 2010 Oct 13-15. Geneva: WHO; 2010, p. 4-8.

25. Gunnarsdottir MJ, Gardarsson SM, Elliott M, Sigmundsdottir G, Bartram J. Benefits of water safety plans: microbiology, compliance, and public health. Environ Sci Technol 2012;46(14): 7782-7789.

26. World Health Organization. UN-water global analysis and assessment of sanitation and drinking-water (GLAAS) 2017 report: financing universal water, sanitation and hygiene under the sustainable development goals; 2017 [cited 2017 Sep 8]. Available from: http://apps.who.int/iris/bitstream/10665/ 254999/1/9789241512190-eng.pdf?ua $=1$. 